\title{
Relative Motion between St. Croix and the Puerto Rico-Northern Virgin Islands Block Derived from Continuous GPS Observations (1995-2014)
}

\author{
Hanlin Liu and Guoquan Wang \\ Department of Earth and Atmospheric Sciences, University of Houston, Houston, TX 77204, USA \\ Correspondence should be addressed to Hanlin Liu; hliu30@uh.edu
}

Received 17 June 2015; Accepted 6 August 2015

Academic Editor: Semih Ergintav

Copyright (C) 2015 H. Liu and G. Wang. This is an open access article distributed under the Creative Commons Attribution License, which permits unrestricted use, distribution, and reproduction in any medium, provided the original work is properly cited.

\begin{abstract}
St. Croix is located inside the sweep of the Lesser Antilles arc and near the southeastern edge of the Greater Antillean ridge. It is separated from the Puerto Rico and the Northern Virgin Islands (PRNVI) block by the Virgin Islands basin. Recent seismic activities demonstrate that the Virgin Islands basin is tectonically active. A better understanding of fault activities in the basin would improve seismic hazard assessment in this region. This study illustrates out a detailed way of deriving relative motion between St. Croix and the PRNVI block using current GPS geodesy infrastructure in the PRVI region. The local geodesy infrastructure includes over 20 continuous GPS stations and a Stable PRNVI Reference Frame (SPRNVIRF). Twenty-year continuous GPS observations (19952014) on St. Croix indicate that the island is presently moving away from the PRNVI block toward the southeast (S55 $\left.{ }^{\circ} \mathrm{E}\right)$ at a steady rate of $1.7 \mathrm{~mm}$ /year. The velocity vector can be decomposed into two $1.2 \mathrm{~mm}$ /year components along the long-axis and short-axis directions of the rhomboidal Virgin Islands basin. Quantitative results indicate that the Virgin Islands basin presently experiences left-lateral motion in a nearly east-west direction and extension in a nearly north-south direction.
\end{abstract}

\section{Introduction}

St. Croix is an island in the Caribbean Sea, about $100 \mathrm{~km}$ east of the Puerto Rico mainland and $60 \mathrm{~km}$ south of the Vieques island. It occupies an important tectonic position in the Caribbean region, located inside the sweep of the Lesser Antilles arc and near the southeastern edge of the Greater Antillean ridge (Figure 1). The island is geographically a part of the Virgin Islands (VI). As a group of islands, the VI starts from east of the Vieques island of Puerto Rico and reaches east to the Anegada Passage. Politically, the eastern islands form the British Virgin Islands (BVI) and the western ones form the U.S. Virgin Islands (USVI). BVI comprises the Tortola, Virgin Gorda, Jost Van Dyke, and Anegada islands. USVI comprises St. Croix, St. John, St. Thomas, and Water Island. St. Croix is largely different from other islands of VI in geology and tectonic aspects (e.g., [1]). In this study we use the term Northern Virgin Islands (NVI) to represent the VI region that is located to the north of the Virgin Islands basin.
The PRNVI block is bounded by the Puerto Rico trench in the north, by the Muertos trough in the south, by the Mona Passage in the west, and by the Anegada Passage in the east (e.g., [2-5]). The Anegada Passage cuts across the Antilles arc between the Greater and the Lesser Antilles and connects the Whiting basin and Virgin Islands basin in the southwest with the St. Croix basin and Sombrero basin in the northeast (Figure 2). It is the only deep-water passage between the Atlantic Ocean and the Caribbean Sea where Atlantic intermediate water can enter into the Caribbean [6].

Previous researchers have proposed the presence of an independently translating Puerto Rico and the Northern Virgin Islands (PRNVI) microplate within the northeastern Caribbean plate based on analysis of seismicity, geophysical data, regional geology, and Global Positioning System (GPS) data (e.g., [7-11]). St. Croix is separated from PRNVI by the Virgin Islands basin, which forms the southeast boundary of the PRNVI block. The Virgin Islands basin has a rhomboidal shape with a long axis of about $80 \mathrm{~km}$ in a nearly east-west (EW) direction (azimuth: $80^{\circ}$ ) and a short 


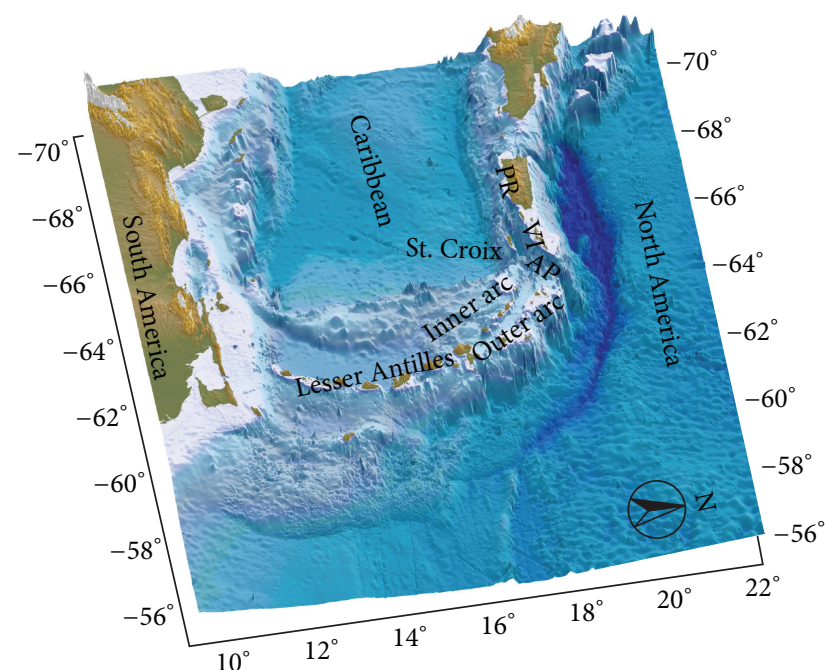

Figure 1: A 3D bathymetric and topographic map showing the locations of the Puerto Rico (PR), Virgin Islands (VI), St. Croix, Anegada Passage (AP), and the Lesser Antilles inner and outer forearcs.

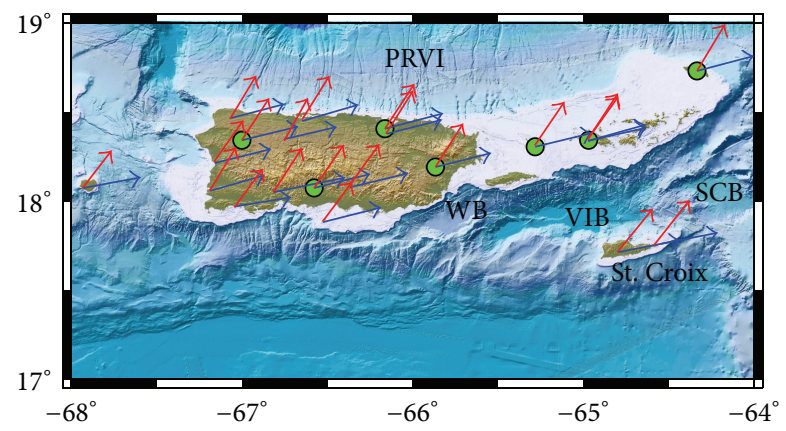

PRVI GPS: velocity vectors within IGS08 and NAD83

$\longrightarrow$ IGS08 (16 mm/year)

$\longrightarrow$ NAD83 (19 mm/year)

FIGURE 2: Velocity vectors of current PRVI continuous GPS stations (>3 years) within the IGS08 (red) and NAD 83(2011) (blue) reference frames. The green dots represent these seven reference stations that are used to establish the stable PRNVI reference frame (SPRNVIRF). The locations of the Whiting basin (WB), Virgin Islands basin (VIB), and St. Croix basin (SCB) are plotted on this map.

axis of about $20 \mathrm{~km}$ in a nearly north-south (NS) direction (azimuth: $170^{\circ}$ ). This basin has a complex bathymetry with the deepest water reaching a depth of over $4500 \mathrm{~m}$ below sea level. Previous investigators proposed different tectonic mechanisms to explain the origin of the basin and present fault motions within the basin. Three controversial faulting motions have been suggested: (1) left-lateral (e.g., [12-18]), (2) right-lateral (e.g., [8,19-22]), and (3) northwest-southeast direction opening across the basin (e.g., [23-26]). This study aims to investigate present relative motion between St. Croix and the PRNVI block, which will provide critical information for understanding the present faulting activities within the Virgin Islands basin and seismic hazards in the PRVI region.

\section{Tectonic Features in the PRVI Region}

The Lesser Antilles, also known as the Caribbees, forms the eastern boundary of the Caribbean plate. The present configuration of the Lesser Antilles island arc is due to the westward underthrusting of the Atlantic oceanic crust under the Caribbean plate. The rate of convergence of this active margin is about $2 \mathrm{~cm} /$ year (e.g., [27-30]). The Lesser Antilles extends from the South American continent to the eastern termination of the Greater Antilles (Puerto Rico and Virgin Islands) (Figure 1). This island arc has a complex history and has probably been active since the Early Cretaceous [31]. The Lesser Antilles forearc diverges from the Anegada Passage to the north of Martinique into an outer (eastern) arc and an inner (western) arc. The outer forearc was volcanically active from Eocene to possibly early Miocene; the inner forearc is volcanically active from late Miocene to present (e.g., $[32,33])$. Tomographic data from $3 \mathrm{D}$ seismic refraction indicate that the inner and outer forearcs are two distinct units with different histories. In general, the inner forearc has a higher vertical velocity gradient than the outer forearc [34]. The inner forearc islands are volcanic in origin, which are still active today, called the "Volcanic Caribbees." The outer forearc consists of sedimentary islands, called the "Limestone Caribbees." There is an intra-arc trough between the outer and inner forearcs, named Kallinago trough [31], which is about 20 to $25 \mathrm{~km}$ wide and stretches from the north of Guadeloupe to Anegada Passage (Figure 1). The age of the Kallinago trough is not well known. According to the geological study of Bouysse and Westercamp [33], the trough originated during the Miocene or younger.

\section{GPS Geodesy Infrastructure in the PRVI Region}

GPS stations were installed in the northeastern Caribbean as early as 1986 for the purpose of studying plate tectonics [35]. These sites were reoccupied for several times in the following years [27]. Jansma and Mattioli have been maintaining a campaign GPS observation network in the PRVI region since the 1990s [9, 10, 36]. Currently, there are more than 20 Continuously Operating Reference GPS Stations (CORS) in the PRVI region [37-39]. Most GPS stations were installed by the Puerto Rico Seismic Network at the University of Puerto Rico at Mayaguez (UPRM). The installation was funded by a National Science Foundation (NSF) Major Research Instrumentation (MRI) project (EAR-0722540). All UPRM GPS data are archived at the UNAVCO public data archiving facility (http://www.unavco.org/data/data.html). A private surveying company, HLCM Group Inc. (http://www.hlcmgroup.com/), also installed eight CORS in the PRVI region for land surveying applications. All data from these HLCM stations are freely available to the public through the CORS data archiving facility (http://www.ngs.noaa.gov/CORS/) operated by the National Geodetic Survey (NGS) at the National Oceanic and Atmospheric Administration (NOAA). Several other agencies, such as the U.S. Coast Guard, International GNSS Service (IGS), and NGS, also operate several continuous GPS 
stations in the PRVI region. This study only used continuous GPS data that are available from the UNAVCO and NGS data archives.

The GIPSY/OASIS (V6.3) software package was employed to calculate daily Precise Point Positioning (PPP) solutions with a single-receiver phase-ambiguity-fixed resolution in this study [40]. The specific configuration for the GIPSY processing is addressed in one of our recent publications [41]. According to our previous statistical studies on the accuracy of the single-receiver phase-ambiguity-fixed PPP solutions, the daily positions would achieve 3 to $5 \mathrm{~mm}$ horizontal accuracy and 6 to $9 \mathrm{~mm}$ vertical accuracy (RMS: root-mean-square) in the PRVI region [38, 42]. The PPP solutions at a single station alone are not sufficient by themselves to precisely track long-term tectonic motions. In order to precisely measure long-term motions at a site, a local reference frame needs to be specified. The GIPSY/OASIS PPP solutions are provided within a geocentric Cartesian coordinate system $(X, Y$, and $Z$ ) which referred to the International GNSS Reference Frame of 2008 (IGS08). This is because the IGS final fiducial orbit frame that referred to IGS08 is used in the PPP processing. In general, a global or a continental-scale reference frame is realized with an approach of minimizing the overall horizontal movements of a large number of selected reference stations (e.g., [29, 4345]). In the case of IGS08, 232 globally distributed and well-performing GPS stations were used [46]. As a result, there are few "stable" (velocity equals zero) stations within a global reference frame.

Figure 2 illustrates the velocity vectors of current PRVI continuous GPS stations with respect to the global reference frame IGS08 and the continental-scale reference frame NAD83(2011) at epoch 2010.00. NAD83(2011) is the latest realization of the North American Datum of 1983 maintained by NGS. These large scale reference frames are realized with an approach of 128 minimizing overall movements of a large number of selected frame stations distributed in North America [47-49].

The high-resolution bathymetry and topography data used in this study are one arc-second $(30 \mathrm{~m})$ digital elevation model (DEM) data from Taylor et al. [50]. The reference frame "NAD83(2011) epoch 2010.00" is the NGS' latest realization of the reference frame fixed to the North American tectonic plate [51]. It appears that the whole PRVI region retains a uniform velocity vector within either IGS08 or NAD83. The horizontal velocity is about $16 \mathrm{~mm} /$ year toward northeast $\left(\mathrm{N} 34^{\circ} \mathrm{E}\right)$ within IGS08 and $19 \mathrm{~mm} /$ year toward the northeast within NAD83 (N77 $\left.{ }^{\circ} \mathrm{E}\right)$. Minor motions (e.g., $<2 \mathrm{~mm}$ /year) associated with local faulting activities could have been overwritten by the "global motions" within IGS08 and the "continental-scale motions" within NAD83. In order to derive minor local ground deformation information over time and space, a stable local reference frame is needed.

The main physical and mathematical properties of a reference frame are the origin, the scale, the orientation, and the change of these parameters over time. In surveying and geodesy, a local reference frame is often realized by a Helmert transformation from a well-established global reference frame. A group of common points (reference stations)
TABLE 1: Fourteen Parameters for the Helmert reference frame transformation from IGS08 to SPRNVIRF.

\begin{tabular}{lcc}
\hline Parameter & Unit & $\begin{array}{c}\text { IGS08 to SPRNVIRF } \\
t_{0}=2013.0\end{array}$ \\
\hline$T x\left(t_{0}\right)$ & $\mathrm{m}$ & 0.0 \\
$T y\left(t_{0}\right)$ & $\mathrm{m}$ & 0.0 \\
$T z\left(t_{0}\right)$ & $\mathrm{m}$ & 0.0 \\
$R x\left(t_{0}\right)$ & Radian & 0.0 \\
$R y\left(t_{0}\right)$ & Radian & 0.0 \\
$R z\left(t_{0}\right)$ & Radian & 0.0 \\
$s\left(t_{0}\right)$ & Unitless & 0.0 \\
$d T x$ & m/year & $4.774470 E-03$ \\
$d T y$ & m/year & $1.072162 E-02$ \\
$d T z$ & m/year & $2.675888 E-02$ \\
$d R x$ & Radian/year & $-3.953039 E-09$ \\
$d R y$ & Radian/year & $-7.142687 E-09$ \\
$d R z$ & Radian/year & $4.537733 E-09$ \\
$d s$ & 1/year & 0.0 \\
\hline
\end{tabular}

${ }^{*}$ Counterclockwise rotations of axes $(X, Y$, and $Z)$ are positive.

are used to tie a local reference to a global reference frame. A local-scale reference frame, named Stable Puerto Rico and Northern Virgin Islands Reference Frame (SPRNVIRF), had been realized by Wang et al. [42]. This local reference frame was originally developed for conducting precise landslide monitoring in the PRVI region. This study updated the previous local reference frame with two additional years (2013 and 2014) of data. The 14 parameters for reference frame transformation from IGS08 to the SPRNVIRF are listed in Table 1.

The selection of reference stations is critical for establishing a precise local reference frame. In this study, seven stations were selected as reference stations. The seven reference stations are PRJC (2009-2014), P780 (2008-2014), BYSP (2008-2014), PRLP (2009-2014), CUPR (2009-2014), VITH (2006-2014), and ABVI (2006-2014) (Figure 2). The averaged three-component velocities of these seven reference stations within the SPRNVIRF are $0.1 \pm 0.05 \mathrm{~mm} /$ year in east-west (EW) direction, $0.2 \pm 0.17 \mathrm{~mm}$ /year in north-south (NS) direction, and $0.5 \pm 0.45 \mathrm{~mm} /$ year in vertical direction. In theory, all reference stations should retain a velocity of zero in the $3 \mathrm{D}$ space within the stable reference frame. However, their $3 \mathrm{D}$ velocities are not exactly zero in practice. The average $3 \mathrm{D}$ velocity of all reference stations indicates the overall stability (precision) of the reference frame. According to our previous study on the precision of local reference frames $[42,52,53]$, the updated SPRNVIRF would be able to distinguish $0.3 \mathrm{~mm} /$ year horizontal displacements and $0.5 \mathrm{~mm} /$ year vertical displacements.

\section{Present Displacement between St. Croix and the PRNVI Block}

There are two long-history continuous GPS stations on St. Croix: CRO1 (1995-2014) and VIKH (2006-2014). These two stations are $23 \mathrm{~km}$ apart. CRO1 is located on the campus of 
the National Radio Astronomy Observatory (NRAO) and it is operated by the Jet Propulsion Laboratory (JPL). The antenna of CRO1 is mounted on a $0.8 \mathrm{~m}$ diameter monolith that is $0.6 \mathrm{~m}$ above the ground surface. VIKH is a CORS located on the campus of the University of the Virgin Islands and it is operated by NGS. The antenna of VIKH is mounted on a metal pipe bored on a side wall of a one-floor concrete building. Figure 3 illustrates the three-component positional time series of VIKH and CRO1 which referred to SPRNVIRF. Three-component site velocities obtained from the 20-year observations (CRO1) are $-0.9 \mathrm{~mm} /$ year (NS), $1.5 \mathrm{~mm} /$ year (EW), and $-0.4 \mathrm{~mm} /$ year (vertical), which indicate that the St. Croix island moves away from the PRNVI block with a horizontal velocity of $1.7 \mathrm{~mm} /$ year $\left(\mathrm{S} 55^{\circ} \mathrm{E}\right)$. The 8 -year observations at VIKH result in exactly the same velocities for the two horizontal components and a slight different velocity ( -0.6 versus $-0.4 \mathrm{~mm} /$ year) for the vertical component. Of course, the 20-year observations provide a higher confidence level than the 8-year observations. A linear regression model is used to calculate the site velocity $(s)$ and standard error $(\sigma)$. Statistically, there is a $95 \%$ possibility that the true site velocity $(v)$ would be located within the band defined by the calculated velocity and $2 \sigma(v=s \pm 2 \sigma)$. In order to eliminate worries that the minor relative movement $(1.7 \mathrm{~mm} /$ year $)$ between the St. Croix island and PRNVI block could be an artifact related to the reference frame transformation, we calculated the baseline between VIKH and VITH with a differential method. The distance (baseline) between VITH and VIKH is approximately $71 \mathrm{~km}$. VITH is a long-history permanent continuous station located on the St. Thomas island. The antenna mount is anchored on the roof of a twofloor concrete building. The single-base carrier phase doubledifference (DD) method employed in the GAMIT/GLOBK (V10.4) [54] software package was used to calculate the baselines between the two stations [54]. Figure 4 depicts the positional time series of VIKH derived from two different approaches: (1) PPP resolutions with respect to the local reference frame SPRNVIRF and (2) DD solutions with respect to a single station (VITH). The positional time series obtained from the two different data processing approaches are parallel to each other and lead to the same interpretation on the relative motion between the St. Croix island and the PRNVI block. The DD method requires simultaneous GPS observations at both the rover (VIKH) and reference (VITH) sites. As a result, no DD solutions were solved at epochs in which the reference station had no data. However, the combination of the PPP processing and the 14-parameter reference frame transformation makes it possible to align all observations at the rover site $(\mathrm{VIKH})$ to a local reference frame.

The Virgin Islands basin is regarded as the western part of the Anegada Passage. Recent seismic activities demonstrate that the Virgin Islands basin area is tectonically active [5557]. The thickness of the sediments in the Virgin Islands basin is up to $2 \mathrm{~km}$ [1]. The sediments are underlain by volcanic basement and the source of the sediments in the basin is the carbonate detritus from the surrounding islands [21]. Previous investigations based on high resolution bathymetry data, seismic survey data, and geologic study suggest that
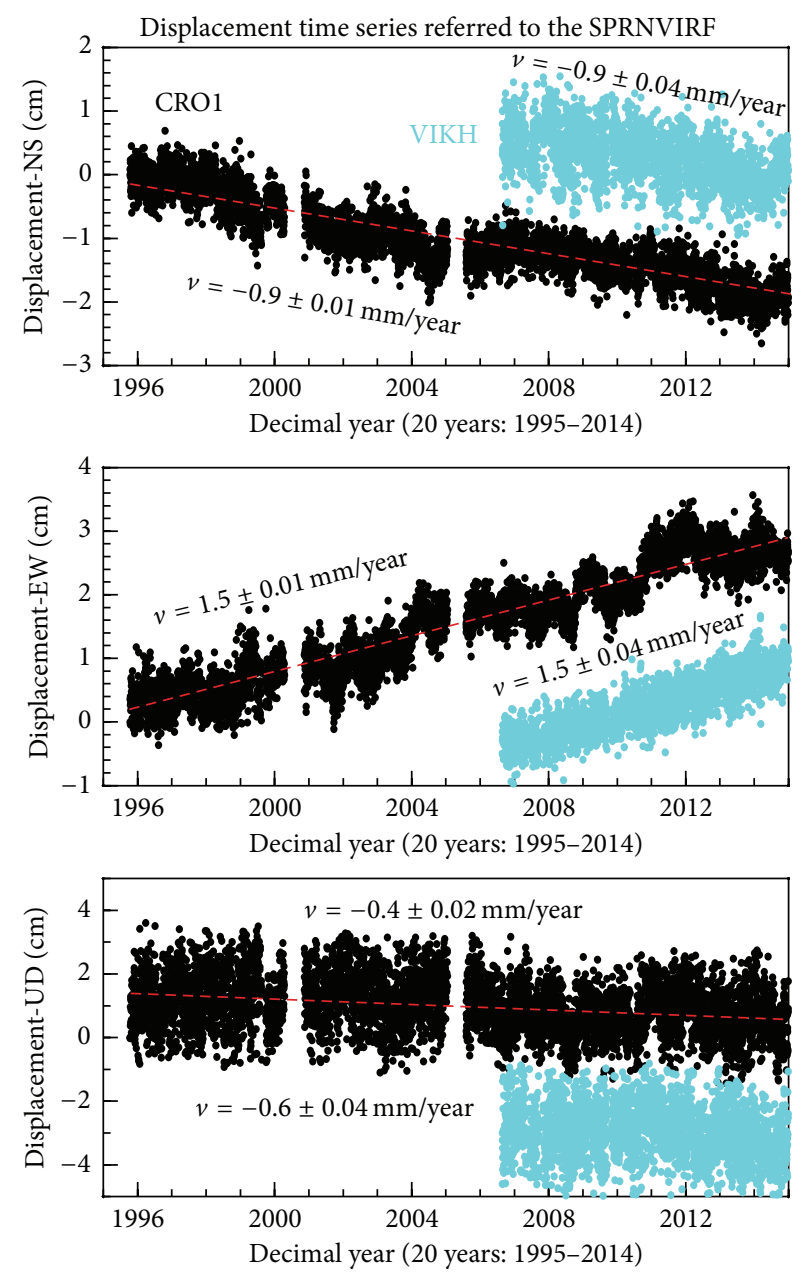

FIGURE 3: Long-term daily positional time series of CRO1 (19952014) and VIKH (2006-2014) referred to the local reference frame SPRNVIRF. CRO1 and VIKH are located on the St. Croix island. The distance between these two GPS stations is $23 \mathrm{~km}$. The linear regression result of the velocity $(v=s \pm 2 \sigma)$ for each positional time series is marked on each subplot. $s$ indicates the velocity (slope) of the site within the SPRNVIRF. $\sigma$ represents the standard error. Statistically, there is a $95 \%$ possibility that the true velocity $v$ will be located within the range from $s-2 \sigma$ to $s+2 \sigma$.

the sedimentary structure within the Virgin Islands basin is characterized by a complex system of strike-slip faults (e.g., [18]), including the one which caused the 1867 Virgin Islands earthquake (M7.5) and tsunami [58, 59]. Most faults strike in near EW or NE-SW directions. No attempt was made in this study to investigate the activity of individual faults. The $1.7 \mathrm{~mm}$ /year southeastern velocity vector (Figure 3 ) recorded on St. Croix could be regarded as a result of the combination of present fault activities within the basin. The overall horizontal movement can be decomposed into a $1.2 \mathrm{~mm} /$ year left-lateral movement in the long-axis direction $\left(\mathrm{N} 80^{\circ} \mathrm{E}\right)$ of the Virgin Islands basin and a $1.2 \mathrm{~mm} /$ year extension in its short axis direction $\left(\mathrm{S} 10^{\circ} \mathrm{E}\right)$ (Figure 5$)$. Thus, the Virgin Islands basin presently experiences a left-lateral motion along a nearly east-west direction and an extension along a nearly north-south direction. A similar model was proposed by 

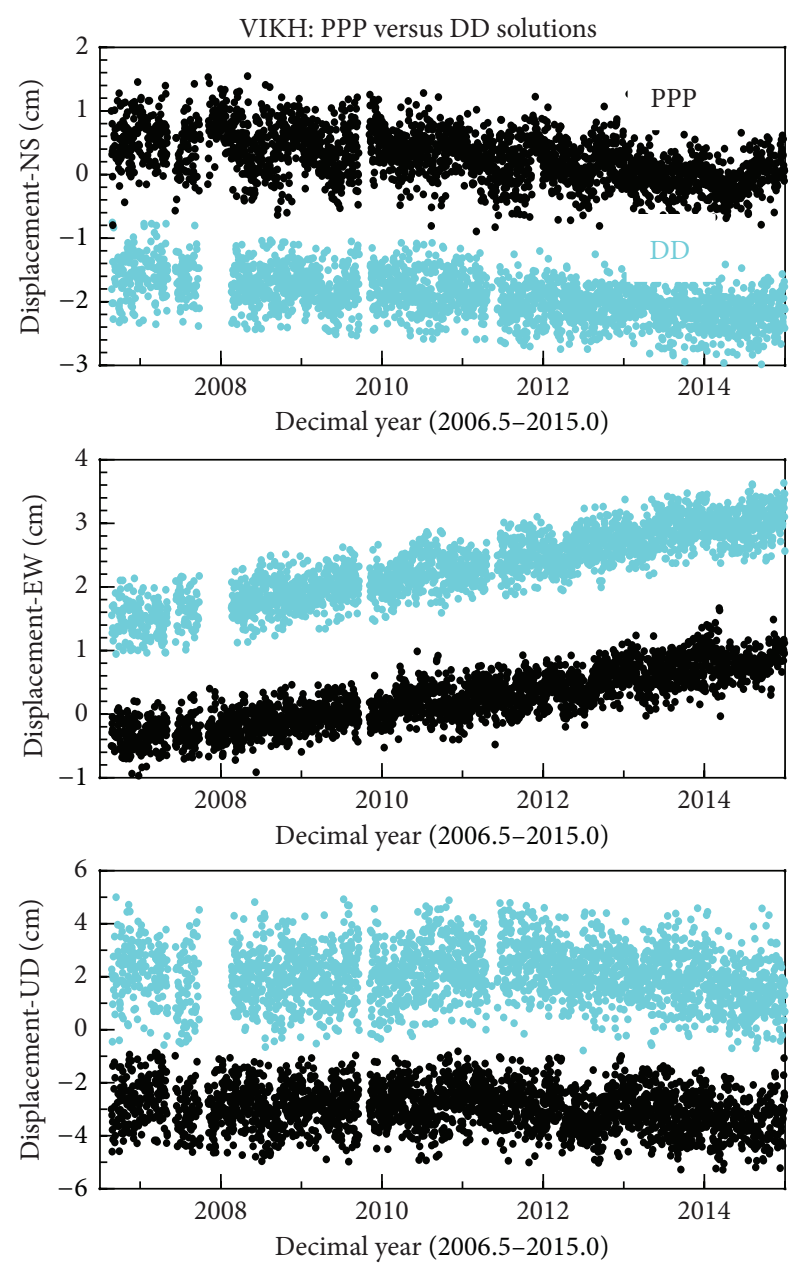

FIgURE 4: Comparisons of daily positions of VIKH (St. Croix) derived from the GIPSY PPP solutions and the GAMIT doubledifference (DD) solutions (VITH fixed). Dark dots represent the PPP solutions which referred to the stable local reference frame SPRNVIRF. Cyan dots represent the DD solutions related to a single fixed station on the St. Thomas island (VITH). The distance between VITH and VIKH is $71 \mathrm{~km}$.

Raussen et al. [18] based on multibeam sonar data (high resolution three dimensional bathymetry data) and seismic survey data.

The vertical positional time series of CRO1 shows a $-0.4 \pm$ $0.02 \mathrm{~mm} /$ year subsidence rate when referred to the PRNVI block (Figure 3), which might indicate the presence of normal faulting in the Virgin Islands basin. In fact, fault geometry deduced from detailed multibeam bathymetry suggests a regional mixed strike-slip and normal faulting in the Virgin Islands basin [59]. However, the $0.4 \mathrm{~mm} /$ year vertical velocity is at the margin of the velocity limits (horizontal: $0.3 \mathrm{~mm} /$ year; vertical: $0.5 \mathrm{~mm} /$ year) that can be distinguished by the current SPRNVIRF. For this reason, we do not intend to do further interpretation on vertical movements in this study. The reference stations used in establishing the current SPRNVIRF mostly have a 5-year history. A longer period of data accumulation will increase the reliability and precision of the vertical measurements.

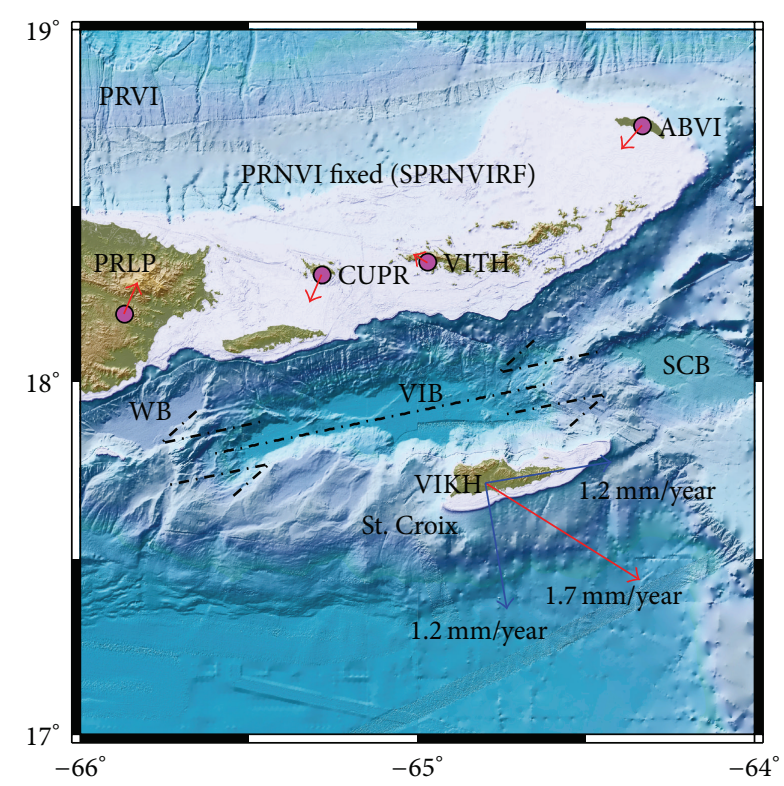

FIGURE 5: An interpretation of the overall faulting within the Virgin Islands basin (VIB). The dark dash-dot line within the Virgin Islands basin does not represent any specific fault. It just depicts the direction of the long-axis of the basin.

\section{Relative Movement between the Lesser Antilles Arc and the PRNVI Block}

Figure 6 depicts the positional time series of two permanent stations (SMRT, BGGY) on the Lesser Antilles outer forearc. The positions have been aligned with the local reference frame SPRNVIRF. SMRT is located on the St. Martin island. It is operated by UNAVCO. This station has a history of over eight years (2007-2014) with a very "clean" positional time series. The horizontal displacement time series indicates that this site is not moving $(<0.05 \mathrm{~mm} /$ year $)$ with respect to the SPRNVI block. BGGY is a continuous GPS station on the Antigua island with a seven-year history (2008-2014). The displacement time series of the EW component shows a near zero velocity $(0.02 \pm 0.02 \mathrm{~mm} /$ year $)$. The NS component of this station shows a minor velocity of $0.6 \mathrm{~mm} /$ year. The velocity of the NS component could be slightly biased by the longperiod motions. A longer time span of observations may result in more reliable velocity estimation. Overall, the longterm positional time series at SMRT and BGGY indicate that the two sites are not moving with respect to the PRNVI block. This in turn implies that the eastern $\left(-64.5^{\circ}\right.$ east $)$ Anegada Passage is presently inactive.

Figure 7 depicts the boundaries of the PRNVI block and the Lesser Antilles Outer Forearc (LAOF) and the velocity vectors which referred to the SPRNVIRF. All GPS stations have a continuous history of over five years. Epicenters of recent earthquakes (1990-2014, $M \geq 4.0)$ are also plotted on this map. The boundary between the Lesser Antilles inner and outer forearcs is drawn out primarily based on previous investigations (e.g., $[25,33,34,60,61])$ ). It appears that the Lesser Antilles inner forearc moves at a similar velocity with St. Croix relative to the PRNVI block. However, the 


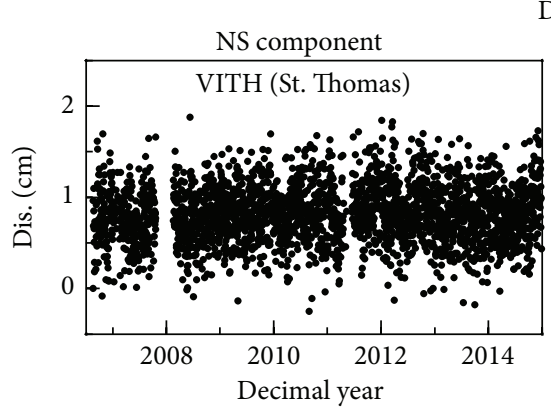

Displacement time series referred to the SPRNVIRF
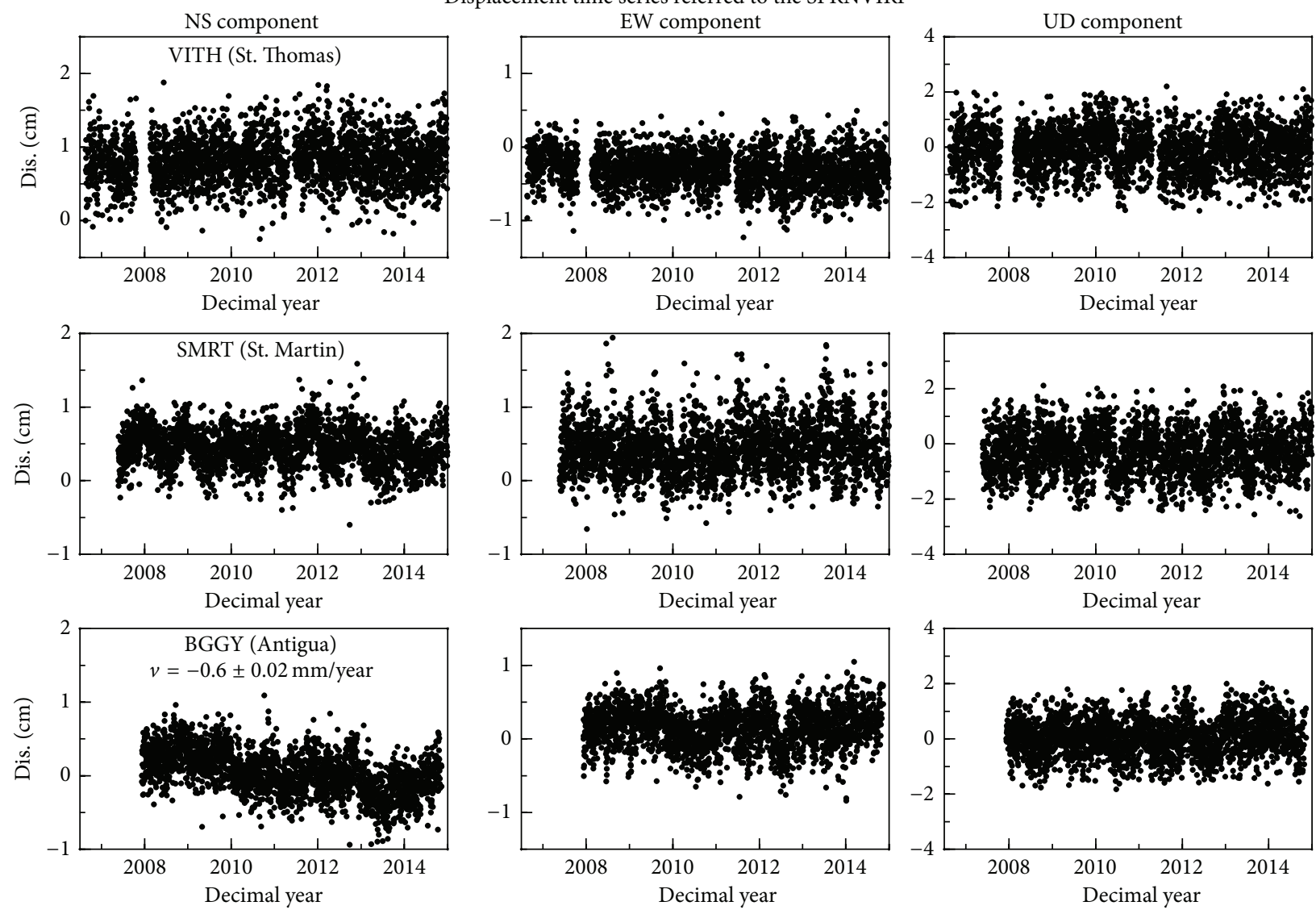

FIGURE 6: Daily positional time series of VITH, SMRT, and BGGY with respect to the SPRNVIRF. VITH is located on the St. Thomas island. It is one of the reference stations that were used to realize the stable local reference frame SPRNVIRF. SMRT and BGGY are two permanent stations on the Lesser Antilles outer forearc.

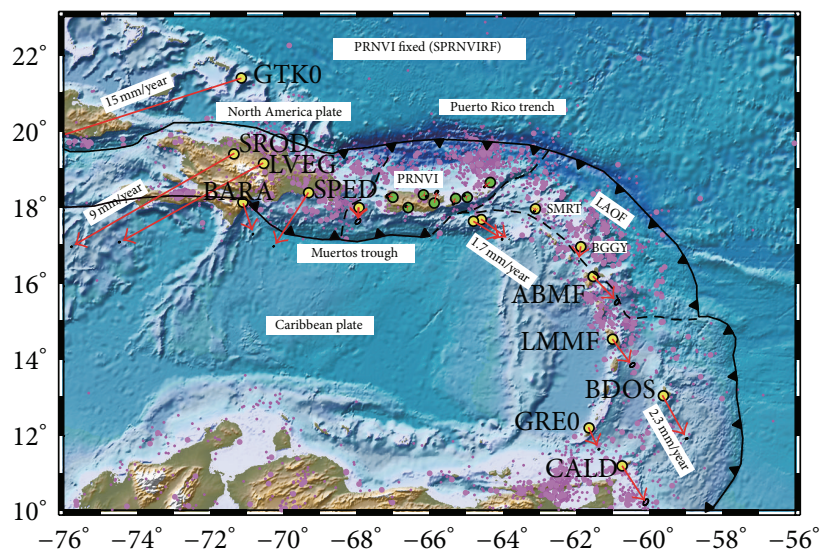

FIGURE 7: Velocity vectors of permanent GPS stations ( $>5$ years) within the PRVI and Lesser Antilles region. The vectors are referred to the SPRNVIRF. The boundary between the Lesser Antilles inner forearc and outer forearc is plotted with a dark dashed line. The small pink dots represent earthquakes (1900-2014) with magnitudes between 4 and 5 (4.0 $\leq M<5.0)$; the big pink dots represent earthquakes (1900-2014) with magnitudes larger than $5.0(M \geq 5.0)$. Earthquake epicenter and magnitude information is obtained from the U.S. Geological Survey Advanced National Seismic System (ANSS) Comprehensive Catalog (http://earthquake.usgs.gov/earthquakes/search/). 
LAOF remains stable relative to the PRNVI block. López et al. [61] proposed the occurrence of a rigid northern Lesser Antilles forearc block based on the systematic discrepancy existing between slip vectors of thrust fault earthquakes at the Lesser Antilles trench and the predicted direction of North American Caribbean convergence. Evain et al. [34] verified the presence of two distinct rigid blocks (inner forearc and outer forearc) within the Lesser Antilles forearc region based on newly acquired $3 \mathrm{D}$ seismic tomographic data. The observations from this study support the presence of a distinct Lesser Antilles outer forearc (LAOF) block.

\section{Conclusions}

Current GPS geodesy infrastructure in the PRVI region makes it possible to delineate minor motions (1 to $2 \mathrm{~mm} /$ year) within the northeastern Caribbean region. The GPS observations presented in this study indicate that St. Croix is moving away from the PRNVI block toward southeast $\left(\mathrm{S} 55^{\circ} \mathrm{E}\right)$ with a steady horizontal velocity of $1.7 \mathrm{~mm}$ /year. Present tectonic motion in the Virgin Islands basin could be characterized by an overall left-lateral motion $(1.2 \mathrm{~mm} /$ year $)$ in the longaxis direction $\left(\mathrm{N} 80^{\circ} \mathrm{E}\right)$ of the basin and by an extension $(1.2 \mathrm{~mm} /$ year $)$ in the short-axis direction $\left(\mathrm{S} 10^{\circ} \mathrm{E}\right)$ of the basin. The GPS data presented in this study also indicate that the Lesser Antilles inner arc moves away from the PRNVI block toward the southeast at a rate of about $2 \mathrm{~mm} /$ year. However, the Lesser Antilles outer forearc presently experiences little movement with respect to the PRNVI block. This implies that the eastern $\left(-64.5^{\circ}\right.$ east $)$ Anegada Passage is presently inactive. The distribution of recent earthquakes (1900-2014) also indicates that there are no significant earthquake activities in the eastern Anegada Passage (Figure 7). A better understanding of the fault activities in the Virgin Islands basin and the Anegada Passage would improve seismic hazard assessment for the PRVI region. The Continuously Operating Caribbean GPS Observational Network (COCONET, http://coconet.unavco.org/) project funded by NSF has installed over 50 permanent GPS stations in the Caribbean region [62]. There are 10 COCONET stations within the Lesser Antilles region. COCONET stations have a history less than three years at the time of this study (the end of 2014) and therefore were not included in this study. The relative motions between the PRNVI block and the Lesser Antilles inner and outer forearcs will be tested in the near future using COCONET data.

\section{Conflict of Interests}

The authors declare that there is no conflict of interests regarding the publication of this paper.

\section{Acknowledgments}

This study was supported by the NSF COCONET Award (EAR-1042906) and an NSF CAREER Award EAR-1229278. Figures were produced using Generic Mapping Tools software [63]. The authors appreciate the geodesy community for sharing GPS data through UNAVCO and NGS.

\section{References}

[1] I. P. Gill, D. K. Hubbard, P. Mclaughlin, and C. H. Moore, "Sedimentological and tectonic evolution of Tertiary St. Croix," in Terrestrial and Marine Geology of St. Croix, D. K. Hubbard, Ed., pp. 49-71, West Indies Laboratory, Saint Croix, US Virgin Islands, 1989.

[2] D. K. Larue and H. Ryan, "Extensional tectonism in the Mona Passage, Puerto Rico and Hispaniola: a preliminary study," in Proceedings of the 12th Caribbean Geological Conference, pp. 223-231, Saint Croix, US Virgin Islands, August 1989.

[3] D. Larue and H. Ryan, "Seismic reflection profiles of the Puerto Rico trench: shortening between the North American and Caribbean plates," in Tectonics and Geochemistry of the Northeastern Caribbean, E. Lidiak and D. Larue, Eds., Geological Society of America Special Paper 322, pp. 193-210, The Geological Society of America, Boulder, Colo, USA, 1998.

[4] A. Mercado and W. McCann, "Numerical simulation of the 1918 Puerto Rico tsunami," Natural Hazards, vol. 18, no. 1, pp. 57-76, 1998.

[5] J. D. Chaytor and U. S. ten Brink, "Extension in mona passage, Northeast Caribbean," Tectonophysics, vol. 493, no. 1-2, pp. 7492, 2010.

[6] D. M. Fratantoni, R. J. Zantopp, W. E. Johns, and J. L. Miller, "Updated bathymetry of the Anegada-Jungfern Passage complex and implications for Atlantic inflow to the abyssal Caribbean Sea," Journal of Marine Research, vol. 55, no. 5, pp. 847-860, 1997.

[7] D. B. Byrne, G. Suarez, and W. R. Mccann, "Muertos trough subduction-microplate tectonics in the northern Caribbean?" Nature, vol. 317, no. 6036, pp. 420-421, 1985.

[8] D. G. Masson and K. M. Scanlon, "The neotectonic setting of Puerto Rico," Geological Society of America Bulletin, vol. 103, no. 1, pp. 144-154, 1991.

[9] P. E. Jansma, G. S. Mattioli, A. Lopez et al., "Neotectonics of Puerto Rico and the Virgin Islands, northeastern Caribbean, from GPS geodesy," Tectonics, vol. 19, no. 6, pp. 1021-1037, 2000.

[10] P. E. Jansma and G. S. Mattioli, "GPS results from Puerto Rico and the Virgin Islands: constraints on tectonic setting and rates of active faulting," GSA Special Papers, vol. 385, pp. 13-30, 2005.

[11] B. Benford, C. DeMets, B. Tikoff, P. Williams, L. Brown, and M. Wiggins-Grandison, "Seismic hazard along the southern boundary of the Gônave microplate: block modelling of GPS velocities from Jamaica and nearby islands, northern Caribbean," Geophysical Journal International, vol. 190, no. 1, pp. 59-74, 2012.

[12] H. H. Hess and J. C. Maxwell, "Caribbean research project," Geological Society of America Bulletin, vol. 64, no. 1, pp. 1-6, 1953.

[13] T. W. Donnelly, "Evolution of Eastern greater Antillean island arc," AAPG Bulletin, vol. 48, no. 5, pp. 680-696, 1964.

[14] P. Mann and K. Burke, "Cenozoic rift formation in the northern Caribbean,” Geology, vol. 12, no. 12, pp. 732-736, 1984.

[15] C. Lithgow, W. R. McCann, and J. Joyce, "Extensional tectonics at the eastern edge of the Puerto Rico platelet," Eos, vol. 44, p. 1483, 1987.

[16] I. Gill, P. P. Mclaughlin Jr., and D. K. Hubbard, "Evolution of the neogene kingshill basin of St. Croix, U.S. Virgin Islands," in Sedimentary Basins of the World, vol. 4, pp. 343-366, Elsevier, 1999.

[17] U. Ten Brink, "Vertical motions of the Puerto Rico Trench and Puerto Rico and their cause," Journal of Geophysical Research B: Solid Earth, vol. 110, no. 6, pp. 1-16, 2005. 
[18] S. Raussen, H. Lykke-Andersen, and A. Kuijpers, "Tectonics of the virgin islands basin, north eastern caribbean," Terra Nova, vol. 25, no. 3, pp. 252-257, 2013.

[19] M. C. Nemec, "A two-phase model for the tectonic evolution of the Caribbean," in Proceedings of the 9th Caribbean Geological Conference, pp. 23-34, Santo Domingo, Dominican Republic, 1980.

[20] J. Matthews and J. Holcombe, "Possible Caribbean underthrusting of the greater Antilles along the Muertos Trough," in Proceedings of the 7th Caribbean Geological Conference, pp. 235242, Guadeloupe, France, 1976.

[21] I. Jany, K. M. Scanlon, and A. Mauffret, "Geological interpretation of combined Seabeam, Gloria and seismic data from Anegada Passage (Virgin Islands, north Caribbean)," Marine Geophysical Researches, vol. 12, no. 3, pp. 173-196, 1990.

[22] P. Loureiro, Cenozoic basin evolution of the Virgin Islands basin and Anegada Passage, Northeastern Caribbean [M.S. thesis], Department of Earth and Atmospheric Sciences, University of Houston, Houston, Tex, USA, 2014.

[23] A. J. Murphy and W. R. McCann, "Preliminary results from a new seismic network in the Northeastern Caribbean," Bulletin of the Seismological Society of America, vol. 69, pp. 1497-1513, 1979.

[24] R. C. Speed and D. K. Larue, "Extension and transtension in the plate boundary zone of the northeastern Caribbean," Geophysical Research Letters, vol. 18, no. 3, pp. 573-576, 1991.

[25] N. Feuillet, I. Manighetti, P. Tapponnier, and E. Jacques, "Arc parallel extension and localization of volcanic complexes in Guadeloupe, Lesser Antilles," Journal of Geophysical Research B: Solid Earth, vol. 107, no. 12, pp. 1-29, 2002.

[26] P. Mann, C. S. Prentice, J.-C. Hippolyte, N. R. Grindlay, L. J. Abrams, and D. Laó-Dávila, "Reconnaissance study of late quaternary faulting along Cerro Goden fault zone, Western Puerto Rico," in Tectonics and Geochemistry of the Northeastern Caribbean, Geological Society of America Special Paper 385, pp. 115-137, The Geological Society of America, Boulder, Colo, USA, 2005.

[27] T. H. Dixon, F. Farina, C. DeMets, P. Jansma, P. Mann, and E. Calais, "Relative motion between the Caribbean and North American plates and related boundary zone deformation from a decade of GPS observations," Journal of Geophysical Research, vol. 103, pp. 15157-15182, 1998.

[28] C. DeMets, P. E. Jansma, G. S. Mattioli et al., "GPS geodetic constraints on Caribbean-North America plate motion," Geophysical Research Letters, vol. 27, no. 3, pp. 437-440, 2000.

[29] C. DeMets, G. Mattioli, P. Jansma, R. D. Rogers, C. Tenorio, and H. L. Turner, "Present motion and deformation of the Caribbean plate: constraints from new GPS geodetic measurements from Honduras and Nicaragua," in Geologic and Tectonic Development of the Caribbean Plate in Northern Central America, P. Mann, Ed., vol. 428 of GSA Special Papers, pp. 21-36, The Geological Society of America, 2007.

[30] P. Mann, E. Calais, J.-C. Ruegg, C. DeMets, P. E. Jansma, and G. S. Mattioli, "Oblique collision in the northeastern Caribbean from GPS measurements and geological observations," Tectonics, vol. 21, no. 6, pp. -1-26, 2002.

[31] P. Bouysse, "The Lesser Antilles island arc: structure and geodynamic evolution," Initial Reports, Deep Sea Drilling Project, 1984.

[32] P. H. A. Martin-Kaye, "A summary of the geology of the Lesser Antilles," Overseas Geology and Mineral Resources, vol. 10, no. 3, pp. 172-206, 1969.
[33] P. Bouysse and D. Westercamp, "Subduction of Atlantic aseismic ridges and Late Cenozoic evolution of the Lesser Antilles island arc," Tectonophysics, vol. 175, no. 4, pp. 349-380, 1990.

[34] M. Evain, A. Galve, P. Charvis et al., "Structure of the Lesser Antilles subduction forearc and backstop from 3D seismic refraction tomography," Tectonophysics, vol. 603, pp. 55-67, 2013.

[35] T. H. Dixon, G. Gonzalez, S. M. Lichten, and E. Katsigris, "First epoch geodetic measurements with the Global Positioning System across the northern Caribbean plate boundary zone," Journal of Geophysical Research, vol. 96, no. 2, pp. 2397-2415, 1991.

[36] E. Calais, Y. Mazabraud, B. M. de Lépinay, P. Mann, G. Mattioli, and P. Jansma, "Strain partitioning and fault slip rates in the northeastern Caribbean from GPS measurements," Geophysical Research Letters, vol. 29, no. 18, article 1856, pp. 3-1-3-4, 2002.

[37] G. Wang and T. Soler, "Opus for horizontal subcentimeteraccuracy landslide monitoring: case study in the Puerto Rico and Virgin Islands Region," Journal of Surveying Engineering, vol. 138, no. 3, pp. 143-153, 2012.

[38] G. Q. Wang, "Millimeter-accuracy GPS landslide monitoring using Precise Point Positioning with Single Receiver Phase Ambiguity (PPP-SRPA) resolution: a case study in Puerto Rico," Journal of Geodetic Science, vol. 3, no. 1, pp. 22-31, 2013.

[39] L. Yang, G. Wang, Y. Bao, T. Kearns, and J. Yu, "Comparisons of ground-based and building-based CORS: a case study in the Puerto Rico and Virgin Islands region," Journal of Surveying Engineering, In press.

[40] W. Bertiger, S. D. Desai, B. Haines et al., "Single receiver phase ambiguity resolution with GPS data," Journal of Geodesy, vol. 84, no. 5, pp. 327-337, 2010.

[41] G. Wang and T. Soler, "Measuring land subsidence using GPS: ellipsoid height versus orthometric height," Journal of Surveying Engineering, vol. 141, no. 2, 2015.

[42] G. Wang, T. J. Kearns, J. Yu, and G. Saenz, "A stable reference frame for landslide monitoring using GPS in the Puerto Rico and Virgin Islands region," Landslides, vol. 11, no. 1, pp. 119-129, 2014.

[43] C. DeMets, R. G. Gordon, D. F. Argus, and S. Stein, "Current plate motions," Geophysical Journal International, vol. 101, no. 2, pp. 425-478, 1990.

[44] K. M. Larson, J. T. Freymueller, and S. Philipsen, "Global plate velocities from the Global Positioning System," Journal of Geophysical Research B: Solid Earth, vol. 102, no. 5, pp. 99619981, 1997.

[45] Z. Altamimi, X. Collilieux, J. Legrand, B. Garayt, and C. Boucher, "ITRF2005: a new release of the international terrestrial reference frame based on time series of station positions and earth orientation parameters," Journal of Geophysical Research, vol. 112, Article ID B09401, 2007.

[46] P. Rebischung, J. Griffiths, J. Ray, R. Schmid, X. Collilieux, and B. Garayt, "IGS08: the IGS realization of ITRF2008," GPS Solutions, vol. 16, no. 4, pp. 483-494, 2012.

[47] R. A. Snay, "Using HTDP software to transform spatial coordinates across time and between reference frames," Surveying and Land Information Systems, vol. 59, no. 1, pp. 15-25, 1999.

[48] R. A. Snay and T. Soler, "Modern terrestrial reference systems. Part 2: the evolution of the NAD 83," Professional Surveyor, vol. 20, no. 2, pp. 16-18, 2000.

[49] T. Soler and R. A. Snay, "Transforming positions and velocities between the international terrestrial reference frame of 2000 
and North American datum of 1983," Journal of Surveying Engineering, vol. 130, no. 2, pp. 49-55, 2004.

[50] L. A. Taylor, B. W. Eakins, K. S. Carignan, R. R. Warnken, T. Sazonova, and D. C. Schoolcraft, "Digital elevation models of Puerto Rico: procedures, data sources and analysis," NOAA Technical Memorandum NESDIS NGDC-13, National Geophysical Data Center, Boulder, Colo, USA, 2008.

[51] C. Pearson, R. McCaffrey, J. L. Elliott, and R. Snay, "HTDP 3.0: software for coping with the coordinate changes associated with crustal motion," Journal of Surveying Engineering, vol. 136, no. 2, pp. 80-90, 2010.

[52] G. Wang, J. Yu, J. Ortega, G. Saenz, T. Burrough, and R. Neill, "A stable reference frame for the study of ground deformation in the Houston metropolitan area, Texas," Journal of Geodetic Science, vol. 3, no. 3, 2013.

[53] G. Wang, Y. Bao, Y. Cuddus, X. Jia, J. Serna, and Q. Jing, "A methodology to derive precise landslide displacement time series from continuous GPS observations in tectonically active and cold regions: a case study in Alaska," Natural Hazards, vol. 77, no. 3, pp. 1939-1961, 2015.

[54] T. Herring, R. King, and S. McClusky, Introduction to GAMIT/GLOBK, Massachusetts Institute of Technology, Cambridge, Mass, USA, 2010.

[55] H. F. Reid and S. Taber, "The Virgin Islands earthquakes of 18671868," Bulletin of the Seismological Society of America, vol. 10, pp. 9-30, 1920.

[56] A. Frankel, W. R. McCann, and A. J. Murphy, "Observations from a seismic network in the Virgin Islands region: tectonic structures and earthquake swarms," Journal of Geophysical Research, vol. 85, no. 5, pp. 2669-2678, 1980.

[57] U. S. Ten Brink, W. H. Bakun, and C. H. Flores, "Historical perspective on seismic hazard to Hispaniola and the Northeast Caribbean region," Journal of Geophysical Research, vol. 116, Article ID B12318, 2011.

[58] W. R. McCann, "On the earthquake hazards of Puerto Rico and the Virgin Islands," Bulletin of the Seismological Society of America, vol. 75, no. 1, pp. 251-262, 1985.

[59] R. Barkan and U. ten Brink, "Tsunami simulations of the 1867 Virgin Island earthquake: constraints on epicenter location and fault parameters," Bulletin of the Seismological Society of America, vol. 100, no. 3, pp. 995-1009, 2010.

[60] G. Wadge and J. B. Shepherd, "Segmentation of the Lesser Antilles subduction zone," Earth and Planetary Science Letters, vol. 71, no. 2, pp. 297-304, 1984.

[61] A. M. López, S. Stein, T. Dixon et al., "Is there a northern Lesser Antilles forearc block?” Geophysical Research Letters, vol. 33, pp. $2-5,2006$.

[62] J. Braun, E. Calais, K. Dausz et al., "COCOnet (continuously operating caribbean gps observational network): infrastructure enhancements to improve sea level monitoring," in Proceedings of the Geological Society of America Annual Meeting, Charlotte, NC, USA, November 2012.

[63] P. Wessel and W. H. F. Smith, "Free software helps map and display data," Eos, Transactions, American Geophysical Union, vol. 72, pp. 441-446, 1991. 

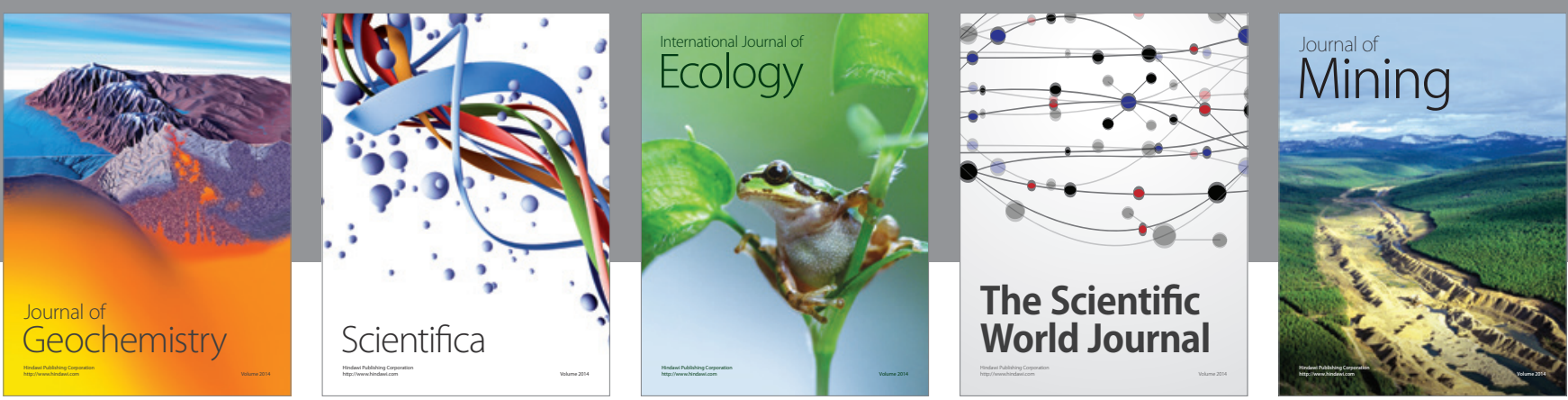

The Scientific World Journal
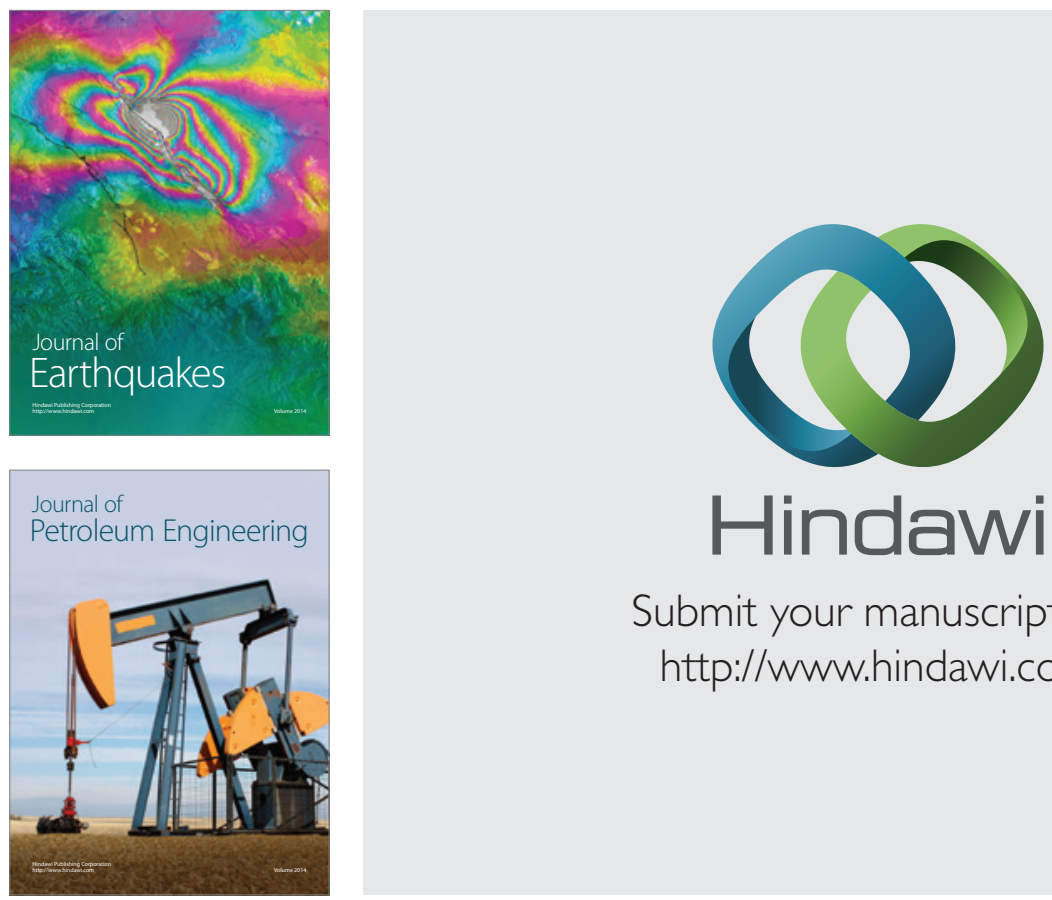

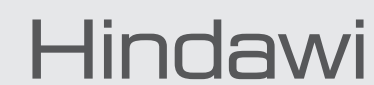

Submit your manuscripts at

http://www.hindawi.com
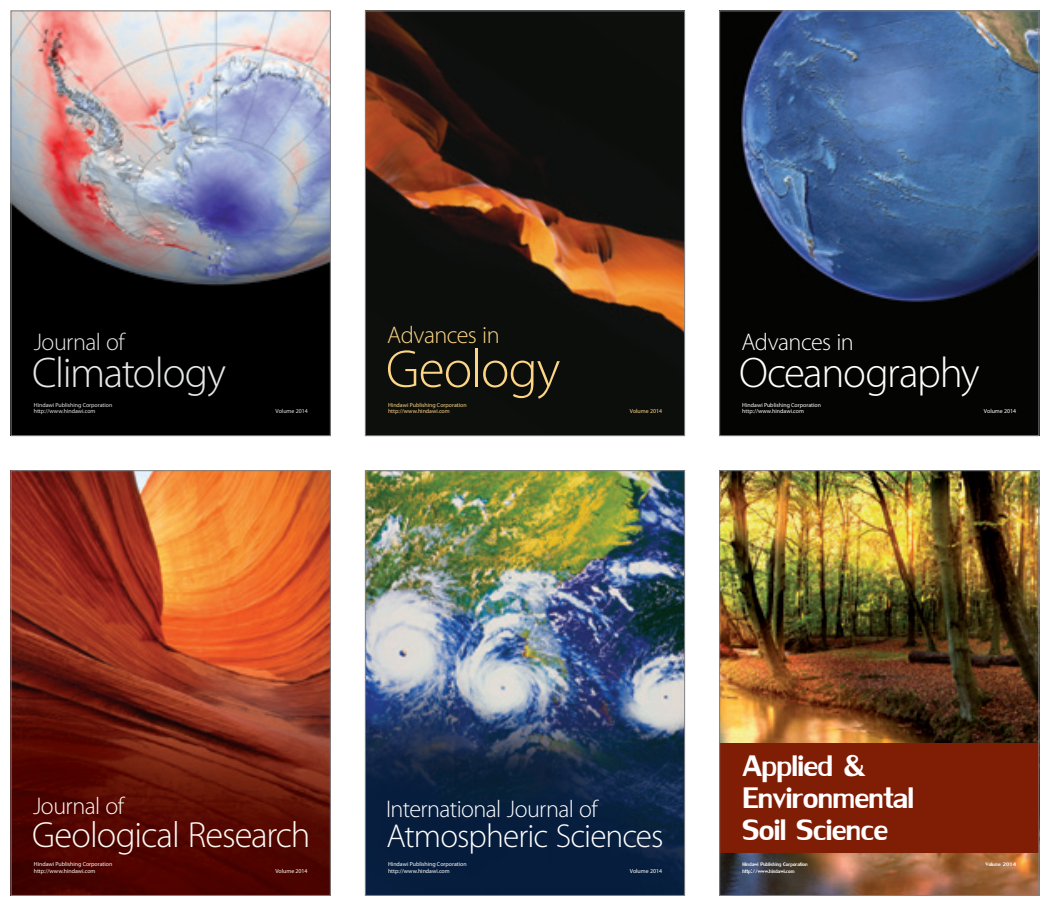
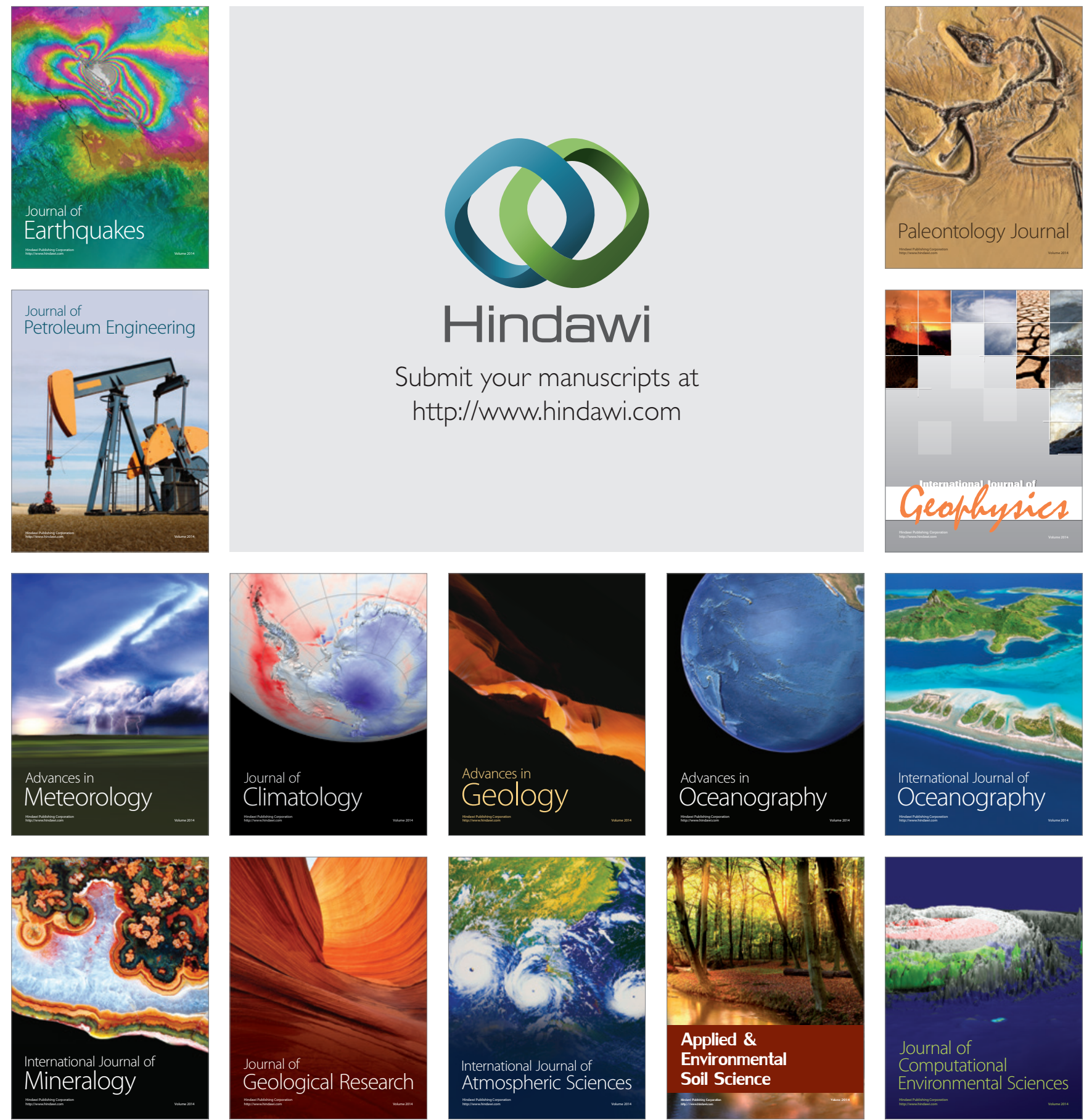